\title{
Editorial
}

\section{Da multidisciplinariedade à aplicação de múltiplos conhecimentos}

\footnotetext{
E

ra, e ainda é, bastante comum a busca da multidisciplinariedade para a solução de problemas. Hoje a formação holística de profissionais busca já prepará-los para atuar com uma base mais ampla, que permita a sua inserção de maneira direta nos mais variados campos do conhecimento. Neste número a RBAV apresenta soluções diversas para múltiplos problemas que possuem uma base comum. Em que se assemelham os satélites e os motores a combustão?! Ou polímeros orgânicos e filmes a base de titânio?! Bem, as modificações de superfícies é uma das respostas! Algumas dessas mudanças foram realizadas em equipamentos de certa forma semelhantes, mas resultaram em respostas bastante distintas. Ou vendo de outra maneira, a partir de diferentes reagentes e equipamentos foram obtidas propriedades semelhantes em diferentes substratos. E tudo isso suportado pela velha e boa tecnologia de vácuo! Isso é o que se espera do profissional do século XXI: que mude o olhar, que pense fora da caixa, que crie e inove, mesmo - ou até preferencialmente - apropriando-se das velhas e consolidadas tecnologias.
}

Álvaro Jose Damião

Antonio Renato Bigansolli

Maria Lúcia Pereira da Silva 